\title{
Effects of Tomato Leaf Curl Virus on Growth and Yield Parameters of Tomato Crop
}

\author{
Yasir Iftikhar ${ }^{1}$, Mustansar Mubeen ${ }^{1 \& 2}$, Ashara Sajid ${ }^{1}$, Muhammad Ahmad Zeshan', Qaiser Shakeel ${ }^{3}$, \\ Aqleem Abbas' ${ }^{2}$, Sonum Bashir ${ }^{1}$, Muhammad Kamran ${ }^{1}$ and Hira Anwaar ${ }^{1}$ \\ (1) Department of Plant Pathology, College of Agriculture, University of Sargodha, Sargodha 40100, Pakistan;
}

(2) State Key Laboratory of Agricultural Microbiology and Provincial Key Laboratory of Plant Pathology of Hubei Province, College of Plant Science and Technology, Huazhong Agricultural University, Wuhan 430070,

Hubei, P.R. China, Email: mustansar01@yahoo.com; (3) Department of Plant Pathology, University College of Agriculture and Environmental Sciences, The Islamia University of Bahawalpur, Bahawalpur, Pakistan

\begin{abstract}
Iftikhar, Y., M. Mubeen, A. Sajid, M.A. Zeshan, Q. Shakeel, A. Abbas, S. Bashir, M. Kamran and H. Anwaar. 2021. Effects of Tomato Leaf Curl Virus on Growth and Yield Parameters of Tomato Crop. Arab Journal of Plant Protection, 39(1): 79-83.

Tomato is an important vegetable crop, belongs to the family Solanaceae and is the second most consumed vegetable following potatoes. The tomato crop is grown all over the world in both summer and winter seasons, and plant viruses are a major threat to tomato production. Among these viruses, tomato leaf curl virus (TLCV) causes considerable yield loss to tomato crop. This virus is transmitted by a whitefly (Bemisia tabaci) vector. In this study, the effect of TLCV infection, on the following tomato growth and yield parameters, was evaluated: plant leaf number and area, plant biomass, plant height, root length, and plant stem diameter and yield. Tomato plants were transplanted in wellprepared plots with 4 replications. The control group was covered with polyethene bag to avoid whitefly infestation. Plants were scored on the $15^{\text {th }}$ and $30^{\text {th }}$ day after inoculation and TLCV disease severity was recorded. Analysis of variance (ANOVA) showed the significant differences between the healthy and infected tomato plants. Moreover, growth and yield parameters were reduced with the increase in disease incidence, disease severity and whitefly infestation. Disease severity was increased with the increase in temperature during the growing season. It can be concluded from this study that TLCV significantly affects growth and yield of the tomato crop.

Keywords: Tomato, Tomato leaf curl virus, TLCV, disease incidence, disease severity.
\end{abstract}

\section{Introduction}

Tomato (Lycopersicon esculentum) belongs to family Solanaceae. It is a very important crop and can be grown in both summer and winter seasons. Tomatoes contribute towards a healthy diet by providing rich amount of minerals, essential amino acids, sugars and fibre (Gerhardt et al., 2009). The optimum temperature range for the growth and flowering of tomato is $21-24^{\circ} \mathrm{C}$.

In Pakistan, tomato crop is grown on 48030 thousand hectares with an average yield of $9500 \mathrm{~kg} / \mathrm{hectare}$ (Arooj et al., 2019). Pakistan is far behind in tomato production in terms of yield/ha compared to India and China. Exports of Pakistani tomato is limited to Afghanistan due to low quality and sometimes it is imported from the neighbouring countries to meet the domestic need (Tahir et al., 2012). In Pakistan the area under tomato cultivation is large but the factors behind the crop low quality and quantity are numerous including farmer economic conditions, farmer training, cultural practices and biotic factors. Among the biotic factors, viral diseases are also hindering the quality and quantity of tomato production (Hanssen et al., 2010). Up to 70 different viruses were reported to affect the growth and yield of tomato crop globally (Thornberry, 1966). Tomato leaf curl disease is considered a severe hazard to tomato crop production (Hanssen et al.,2010). This composite of viruses in India, Pakistan and Australia region is known as Tomato leaf curl virus (TLCV) and in Europe and Middle East region it is called Tomato yellow leaf curl virus (TYLCV) (Pandey et al., 2009). TLCV was initially reported in the 1980s in Sudan and is transmitted through whitefly (Bemesia tabaci) as a natural insect vector (Sugano et al., 2011).

TLCV belongs to the genus Begomovirus (Fondong et al., 2013) and transmitted by the whitefly Bemisia tabaci in a circulative (persistent) manner (Chen et al., 2016). The disease is also transmitted by grafting to healthy tomato and other hosts (Arooj et al.,2019). Tomato leaf curl disease is reported to prevail in most tomato producing regions of the world (Li et al., 2009). TLCV disease causes severe economic losses up to $100 \%$ in most tomato producing region of the world (Lefeuvre et al., 2010). TLC disease symptoms of infected plants include stunting, wrinkling of leaves and yellowing between the veins, upward curling of leaf margins giving leaves a cup-shape appearance, with flower drop occurs before fruit setting (Burko et al., 2013). The main objective of the present research was to investigate the effect of TLCV infection on growth and yield of tomato crop in relation to whitefly infestation in Pakistan.

\section{Materials and Methods}

The experiment was conducted in the College of Agriculture, University of Sargodha, Pakistan, during 2017/2018 growing season. Healthy tomato seeds of variety Nagina were

https://doi.org/10.22268/AJPP-039.1.079083

(C) 2021 Arab Society for Plant Protection الجمعية العربية لوقاية النبات 
obtained from the Department of Horticulture, College of Agriculture, University of Sargodha, Pakistan. Germination of seeds was tested by the wet towel method. Tomato seeds were surface disinfected by soaking them in $10 \%$ tri-sodium phosphate for 30 minutes. The 30-35 days old seedlings were transferred to the field.

\section{Disease incidence and rating}

Plants usually displayed symptoms 15 days after transplanting. Plants were randomly selected for data collection. Disease incidence data was scored every 15 days from 30 to 75 days after planting. Tomato leaf curl virus disease incidence (\%) was calculated using the following formula (Allen et al., 1983):

Disease incidence $(\%)=\frac{\text { Number of infected plants }}{\text { Total number of plants }} \times 100$

Tomato plants were rated based on a $0-5$ scale to evaluate their field reaction to infection following the disease rating scale of Lapidot et al. (2001), which is as follows: $0=$ No infection (highly resistant), $1=1-20 \%$ infection (resistant), $2=21-40 \%$ infection (moderately resistant), $3=41-60 \%$ infection (moderately susceptible), $4=$ $61-80 \%$ infection (susceptible), $5=81-100 \%$ infection (highly susceptible).

\section{Bemisia tabaci infestation}

The whitefly vector population increased with increased growth of the tomato plant. The data was recorded one week after planting and then at maximum virus infection level.

\section{Growth and yield parameters assessment}

Plant height - Five healthy as well as five diseased plants were randomly selected from each plot. Each plant was laid straight on the floor and their length was measured from the base to the tip of the plant. Average of tomato height was calculated by using the following formula:

$$
\text { Average height }=\frac{\text { Height of all plants }}{\text { Number of plants }}
$$

Yield per plant - Five healthy as well as five diseased plants were selected randomly from each plot. Tomato fruitswere collected from each plant and weighed. Average of tomato fruit/plant was calculated by using the following formula:

$$
\text { Fruit yield/plant }=\frac{\text { Weight of all collected fruits }}{\text { Number of plants }}
$$

Number of fruits - Five healthy as well as five diseased plants were randomly selected from each plot. Tomato fruits were collected from each plant and counted. The average number of tomato fruits/plant was calculated using the following formula:

Number of fruits/plant $=\frac{\text { Total number of all collected fruits }}{\text { Number of plants }}$
Experimental design and stastical analysis

The collected data was transferred to MS Excel. Disease incidence was calculated on MS Excel.

All the recorded data was statistically analyzed and possible interactions was determined through ANOVA and the treatment was compared by LSD test at 5\% level of probability (Steel et al., 1997).

\section{Results}

The response of tomato germplasm to TLCV Infection Disease incidence of three different planting dates was recorded 30, 45, 60 and 75 days after planting (Table1).The TLCV incidence at 30 days after tomato planting ranged from 8.32 to $25 \%$. 45 days after planting, TLCV incidence ranged from 18.72 to $56.16 \%$. 60 days after planting TLCV incidence ranged between 35.36 and $72.8 \%$, whereas maximum disease incidence was observed 75days after planting (56.16-89.44\%). Early planting tended to slightly reduce TLCV incidence. This may be due to disease escape because of reduced vector activity.

Table 1. TLCV incidence (\%) on Tomato crop during 2017/2018 growing season with three different planting dates.

\begin{tabular}{lcccc}
\hline & \multicolumn{4}{c}{ Days after planting } \\
\cline { 2 - 5 } Planting date & $\mathbf{3 0}$ & $\mathbf{4 5}$ & $\mathbf{6 0}$ & $\mathbf{7 5}$ \\
\hline 15 January & $8.32 \mathrm{c}$ & $18.72 \mathrm{c}$ & $35.36 \mathrm{c}$ & $56.16 \mathrm{c}$ \\
15 February & $25.00 \mathrm{a}$ & $56.16 \mathrm{a}$ & $62.40 \mathrm{~b}$ & $81.12 \mathrm{~b}$ \\
15 March & $12.48 \mathrm{~b}$ & $39.52 \mathrm{~b}$ & $72.80 \mathrm{a}$ & $89.44 \mathrm{a}$ \\
\hline
\end{tabular}

Values followed by the same letters in the same column are not significantly different at $\mathrm{P}=0.05$.

The response of tomato plants to whiteflyinfestation and TLCV infection

The late tomato planting date of 15 March led to maximum TLCV incidence of $60.06 \%$. The readings of disease incidence were obtained after the appearance of first symptoms. Earlier planting dates led to less TYLCV incidence (Table 2). This may be due to the cool temperature during the early season which is not in favor of vector activity.

Table 2. The overall response of tomato plants against TLCV infection and whitefly infestation.

\begin{tabular}{lcc}
\hline $\begin{array}{l}\text { Time of } \\
\text { planting }\end{array}$ & $\begin{array}{c}\text { Number of } \\
\text { whiteflies/ } \\
\text { plant }\end{array}$ & $\begin{array}{c}\text { Average Disease } \\
\text { incidence (\%) } \\
\text { (Based upon weekly } \\
\text { recorded data) }\end{array}$ \\
\hline 15 January & $36 \mathrm{c}$ & $29.64 \mathrm{c}$ \\
15 February & $41 \mathrm{~b}$ & $51.92 \mathrm{~b}$ \\
15 March & $50 \mathrm{a}$ & $60.06 \mathrm{a}$ \\
\hline
\end{tabular}

Values followed by the same letters in the same column are not significantly different at $\mathrm{P}=0.05$. 
Effect of TLCV infection on tomato yield and growth parameters

Plant height (cm) - Maximum average of tomato plant height was obtained in the early January planted plots $(60.32 \mathrm{~cm})$, and the lowest average height was obtained in the February planted plots $(55.67 \mathrm{~cm})$ (Table 3$)$.

Number of fruits/plant - The average number of fruits per plant ranged from 25.67 to 42 . The maximum number of fruits was recorded for the January planted plot (42 fruits/plant), followed by the February planting (32 fruits/plant). The minimum number of tomatoes fruits was obtained from the March planting (25.67 fruits/plant) (Table 3).

Fruits weight- Fruit size ranged from 29 to $43 \mathrm{~g}$, with maximum size for the January planting $(43 \mathrm{~g}$ ) followed by the February planting (31g), and the minimum fruit weight was recorded for the March planting date (29g) Table 3).

Tomato yield (kg/plant) -Tomato yield ranged from 3.47 to $2.01 \mathrm{~kg} /$ plant. The maximum yield was obtained for the January planting $(3.47 \mathrm{~kg} / \mathrm{plant})$ followed by the February planting (3.15kg/plant), and the minimum yield was recorded for the March planting date $(2.06 \mathrm{~kg} / \mathrm{plant})$ (Table $3)$.

Table 3. Effect of TLCV infection on tomato yield and yield contributing parameters.

\begin{tabular}{lcccc}
\hline $\begin{array}{l}\text { Planting } \\
\text { date }\end{array}$ & $\begin{array}{c}\text { Plant } \\
\text { height } \\
\text { (cm) }\end{array}$ & $\begin{array}{c}\text { No. of } \\
\text { fruits/ } \\
\text { plant }\end{array}$ & $\begin{array}{c}\text { Fruit } \\
\text { weight (g) }\end{array}$ & $\begin{array}{c}\text { Yield (kg/ } \\
\text { plant) }\end{array}$ \\
\hline 15 January & $60.32 \mathrm{a}$ & $42 \mathrm{a}$ & $43 \mathrm{a}$ & $3.47 \mathrm{a}$ \\
15 February & $55.67 \mathrm{c}$ & $31 \mathrm{~b}$ & $31 \mathrm{~b}$ & $3.15 \mathrm{~b}$ \\
15 March & $57.89 \mathrm{~b}$ & $25 \mathrm{c}$ & $29 \mathrm{c}$ & $2.01 \mathrm{c}$ \\
\hline
\end{tabular}

Values followed by the same letters in the same column are not significantly different at $\mathrm{P}=0.05$.

Relationship between TLCV incidence (\%) and whitefly infestation - There was a strong positive correlation between the whitefly population and tomato leaf curl virus disease incidence $(\%)\left(\mathrm{R}^{2}=0.8295\right)$.

Relationship between TLCV incidence(\%) and yield - A moderately negative correlation existed between tomato yield (kg/plant) and tomato leaf curl virus disease incidence $(\%)$, with $\mathrm{R}^{2}=0.5483$. Regression analysis was conducted using MS Excel 2013. $\mathrm{R}^{2}$ value suggest that there was a poor correlation between the two variables.

Relationship between whitefly population and yield - A very strong negative correlation existed between tomato yield ( $\mathrm{kg} /$ plant) and whitefly population, with $\mathrm{R}^{2}=$ 0.9061(MS Excel 2013). In other words, low whitefly population contributed towards high tomato yield.

Relationship between TLCV incidence (\%) and plant height - A strong negative correlation existed between tomato leaf curl virus disease incidence $(\%)$ and plant height, with $\mathrm{R}^{2}=0.8027$ (MS Excel 2013).

Relationship between the whitefly population and plant height - There was a negative correlation between the whitefly population and plant height with $\mathrm{R}^{2}=0.723$ (MS Excel 2013).

\section{Discussion}

In this study, tomato yield and and a number of growth parameters were affected by the different planting dates tested. Less TLCV infection was noticed in the early planting compared to the late planting. Earlier reports indicated that disease incidence was less when the crop was grown at low temperature, and disease incidence increased with a gradual increase in ambient temperature (Zeshan et al., 2016). TLCV symptoms were found mild in winter as compared to spring crop (Singh et al., 2015; Rashid et al., 2008), and high temperature increases the whitefly vector population which ultimately increase the incidence of disease (Mubeen et al., 2017). The current study confirmed that Bemisia tabaci population and TLCV incidence increased with increase in temperature. Munshi and Choudhry (1964) concluded earlier that disease severity significantly and positively correlated with temperature increase.

As Pakistan is a subtropical country, where high temperature prevails, there is a good chance for tomato to be infected with TLCV. In this study, there was a strong negative correlation between TLCV incidence and tomato yield, which is similar to what has been reported earlier (Mugitet al.,2007; Lapidot et al., 1997). Plants infected with TLCV at the very early stage won't bear proper fruit and vegetative growth will be severly affected (Khan et al.,2013). The strong negative correlation exists between tomato yield and whitefly population. Kakati\& Nath (2015) showed that plant raised under net did not exhibit any of TLCV symptoms as compared to uncovered plots, a strong indication that preventing the viruliferous whitefly vector from reaching young tomato plants, in any possible way, will lead to less infection and more yield. 


\section{الملخص}

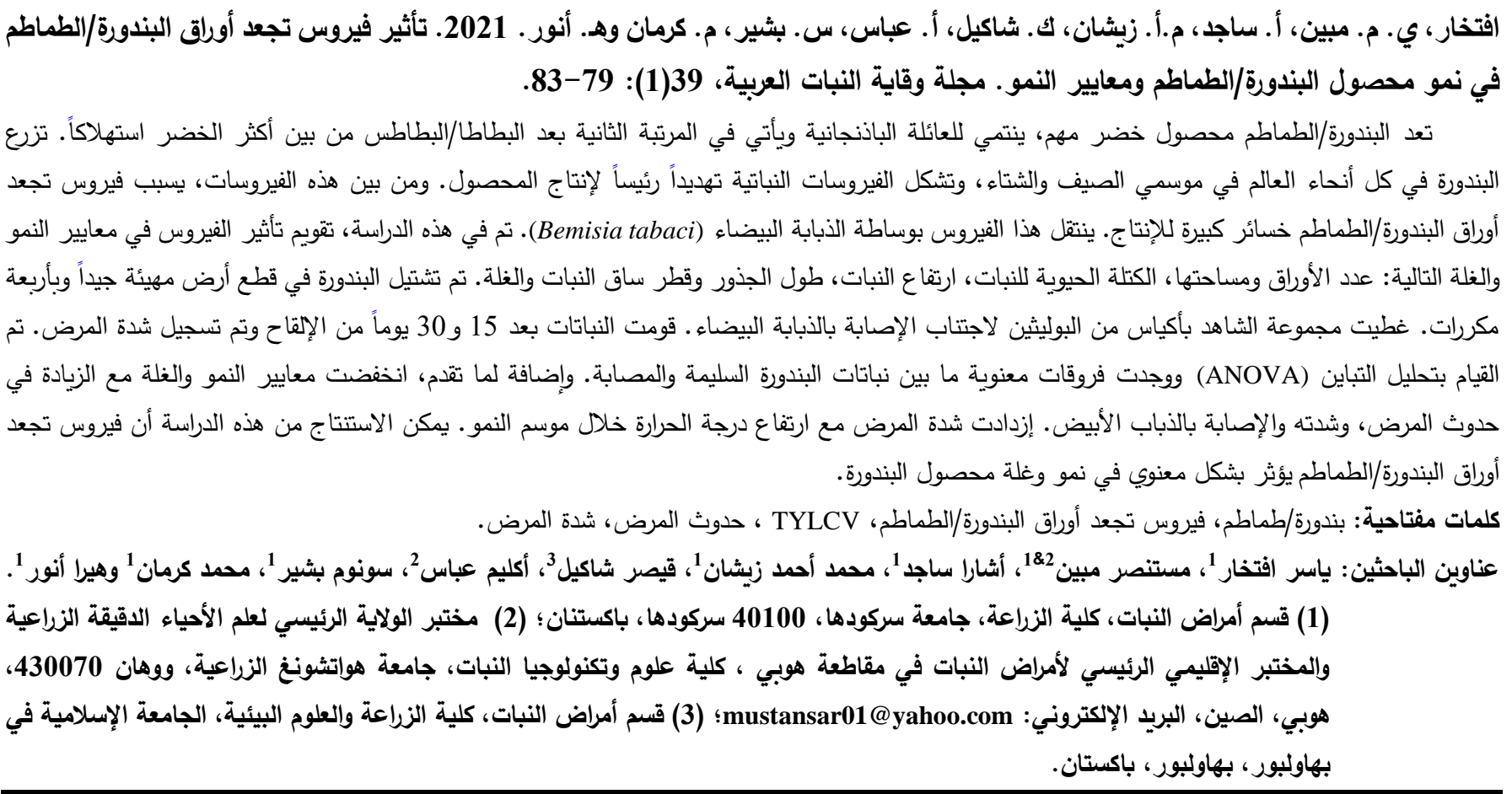

\section{References}

Allen, R.N., R.T. Plumb and J.M. Thresh. 1983. Spread of banana bunchy top and other plant virus diseases in time and space. Pages 51-59. In: Plant Virus Epidemiology. R.T. Plumb and J.M. Thresh (eds.). Blackwell Scientific Publications, Oxford, UK

Arooj, S., Y. Iftikhar, M. Mubeen, M.I. Ullah, A. Sajid, S. Ali, Q. Shakeel, M. Aatif, W. Raza, I.R. Noorka and H.Qudsia. 2019. Effect of environmental factors on biochemical properties of Tomato Leaf Curl Virus infected leaves of Tomato. Pakistan Journal of Phytopathology, 31: 105-111. https://doi.org/10.33866/phytopathol.031.01.0467

Burko, Y., S. Shleizer-Burko, O.Yanai, I.Shwartz, I.D.Zelnik, J. Jacob-Hirsch and N. Ori.2013. A role for apetala1/fruitfull transcription factors in tomato leaf development. Plant Cell, 25: 2070-2083. https://doi.org/10.1105/tpc.113.113035

Chen, W., D.K. Hasegawa, N. Kaur, A. Kliot, P.V. Pinheiro, J. Luan and Y. Xu. 2016. The draft genome of whitefly Bemisia tabaci MEAM1, a global crop pest, provides novel insights into virus transmission, host adaptation, and insecticide resistance. BMC Biology, 14: 110. https://doi.org/10.1186/s12915-016-0321-y

Fondong, V. N. 2013. Geminivirus protein structure and function. Molecular Plant Pathology, 14: 635-649. https://doi.org/10.1111/mpp.12032

Gerhardt, K.E., X.D. Huang, B.R. Glick and B.M. Greenberg. 2009. Phytoremediation and rhizoremediation of organic soil contaminants: potential and challenges. Plant science, 176: 20-30. https://doi.org/10.1016/j.plantsci.2008.09.014
Hanssen, I.M., M. Lapidot and B.P.Thomma. 2010. Emerging viral diseases of tomato crops. Molecular Plant-Microbe Interactions, 23: 539-548 https://doi.org/10.1094/MPMI-23-5-0539

Kakati, N. and P.D. Nath. 2014. Sustainable management of Tomato leaf curl virus disease and its vector, Bemisia tabaci through integration of physical barrier with biopesticides. International Journal of Innovative Research and Development, 3:132-140.

Khan, M.S., A.K. Tiwari, A.A. Khan, S.H. Ji and S.C. Chun. 2013. Current Scenario of tomato yellow leaf curl virus (TYLCV) and its possible management: a review. Vegetos, 26:139-147.

Lapidot, M., M. Friedmann, M. Pilowsky, R. Ben-Joseph and S. Cohen. 2001. Effect of host plant resistance to Tomato yellow leaf curl virus (TYLCV) on virus acquisition and transmission by its whitefly vector. Phytopathology, 91(12): 1209-1213. https://doi.org/10.1094/PHYTO.2001.91.12.1209

Lapidot, M., M. Friedmann, O. Lachman, A. Yehezkel, S.Nahon, S. Cohen and M.Pilowsky. 1997. Comparison of resistance level to tomato yellow leaf curl virus among commercial cultivars and breeding lines. Plant Disease, 81: 1425-1428. https://doi.org/10.1094/PDIS.1997.81.12.1425

Lefeuvre, P., D.P. Martin, G. Harkins, P.Lemey, A.J. Gray, S. Meredith and J. Heydarnejad. 2010. The spread of tomato yellow leaf curl virus from the Middle East to the world. PLoS Pathogens, 6: e1001164. https://doi.org/10.1371/journal.ppat.1001164 
Li, H., X. Ding, C. Wang, H. Ke, Z. Wu, Y. Wang, H. Liu and J. Guo. 2016. Control of Tomato yellow leaf curl virus disease by Enterobacter asburiae BQ9 as a result of priming plant resistance in tomatoes. Turkish Journal of Biology, 40: 150-159. https://doi.org/10.3906/biy-1502-12

Li, W., D.J. Lewandowski, M.E. Hilf and S. Adkins. 2009. Identification of domains of the tomato spotted wilt virus NSm protein involved in tubule formation, movement and symptomatology. Virology, 390: 110121. https://doi.org/10.1016/j.virol.2009.04.027

Mubeen, M., Y. Iftikhar, M.I. Ullah, Q. Shakeel, M. Aatif and I. Bilqees. 2017. Incidence of Okra Yellow Vein Mosaic disease in relation to insect vector and environmental factors. Environment and Ecology, 35: 2215-2220.

Mugit, A. and A.Akanda. 2007. Management of Tomato yellow leaf curl virus through Netting. The Agriculturists, 5: 1-5. https://doi.org/10.3329/agric.v5i1.5191

Munshi, Z. and A.H. Choudhry. 1964. Some correlation studies between temperature and leaf curl incidence in cigarette tobacco. Pakistan Journal of Science, 16(2): 48-52.

Pandey, J. and U. Pandey. 2009. Accumulation of heavy metals in dietary vegetables and cultivated soil horizon in organic farming system in relation to atmospheric deposition in a seasonally dry tropical region of India. Environmental Monitoring and Assessment, 148: 6174.

Rashid, M.H., I. Hossain, A. Hannan, S.A. Uddin and M.A. Hossain. 2008. Effect of different dates of planting time on prevalence of Tomato yellow leaf curl virus and whitefly of tomato. Journal of Soil and Nature, 2: 1-6.

Received: October 5, 2020; Accepted: January 17, 2021
Singh, A.K., V. Dwivedi, A. Rai, S. Pal, S.G.E. Reddy, D.K.V. Rao and D.A.Nagegowda. 2015. Virusinduced gene silencing of Withaniasomnifera squalene synthase negatively regulates sterol and defenserelated genes resulting in reduced with anolides and biotic stress tolerance. Plant Biotechnology Journal, 13: 1287-1299. https://doi.org/10.1111/pbi.12347

Steel, R.G.D., J.H. Torrie and D.A. Dickey. 1997. Principles and procedures of Statistics. A biochemical approach, $3^{\text {rd }}$ Ed. McGraw Hill Book Co. Inc. New York.

Sugano, J., M. Melzer, A. Pant, T. Radovich, S. Fukuda, S. Migita and J. Uyeda. 2011. Tomato yellowleaf curl virus-resistant varieties for commercial production. University of Hawaii, PD-78, 4 pp. http://hdl.handle.net/10125/33260

Tahir, M., F. Anwar, M. Abbas, M.C. Boyce and N. Saari. 2012. Compositional variation in sugars and organic acids at different maturity stages in selected small fruits from Pakistan. International Journal of Molecular Sciences, 13: 1380-1392. https://doi.org/10.3390/ijms13021380

Thornberry, H.H. 1966. Plant pests of importance to North American agriculture. Index of plant virus diseases. Volume 307 of Etats-Unis. Department of Agriculture. Agriculture handbook, U.S. Department of Agriculture. 446 pp.

Vasudeva, R.S. and R.J. Sam.1948. A leaf curl disease of tomato. Phytopathology, 38: 364-369.

Zeshan, M.A., M.A. Khan, S. Ali and M. Arshad. 2016. Phenotypic evaluation of tomato germplasm for the source of resistance against tomato leaf curl virus disease. The Journal of Animal \& Plant Sciences, 26: 194-200.

تاريخ الاستلام: 2020/10/5؛ تاريخ الموافقة على النشر: 2021/1/17 